Doi: 10.30868/ad.v4i02.807

\title{
BUSINESS ETHICS IN THE CONCEPT OF SHARIA LAW
}

\section{ETIKA BISNIS DALAM KONSEP HUKUM SYARIAH}

\author{
${ }^{1}$ Sayyidatunisa, ${ }^{2}$ Reni Seri Lestari, ${ }^{3}$ Shella Titania Nurdin, ${ }^{4}$ Masruroh, ${ }^{5}$ Indah Nur \\ Anisa, ${ }^{6}$ Fitri Nur Latifah \\ Universitas Muhammadiyah Sidoarjo \\ ${ }^{1}$ sayyidatunisa27@gmail.com \\ ${ }^{2}$ reniseri41@gmail.com \\ ${ }^{3}$ shellatitania8@gmail.com \\ ${ }^{4}$ masruroh533@gmail.com \\ 5indahnra09@gmail.com \\ ${ }^{6}$ fitri.latifah@umsida.ac.id
}

\begin{abstract}
In the information ethical Islamic banks, both quantitative and qualitative in aspects of moral and material in terms of the market share of sharia banking in Indonesia is still relatively small in comparison with the share of the conventional market, but in Islamic banking has an annual growth rate which is quite significant, and on the Development of the market share of sharia is quite encouraging but have not yet followed with the application of the principles of business ethics of Islam which is the maximum. However, Islamic banks have implemented the principles of Islamic business ethics in their operations. They have also provided a guide to the stakeholders, such as customer depositors, shareholders, investors, bonds, bank respondents, the regulator, employees of the company, suppliers, and the environmental community to realize public accountability in its efforts to economic decisions.
\end{abstract}

Key word: Business ethics, sharia law, Islam, stakeholders, investors

\begin{abstract}
ABSTRAK
Dalam informasi etis bank syariah baik yang bersifat kuantitatif maupun kualitatif pada aspek moral maupun material dalam hal pangsa pasar perbankan syariah yang ada di Indonesia masih relatif kecil di bandingkan dengan pangsa pasar konvensional namun dalam perbankan syariah mempunyai tingkat pertumbuhan tahunan yang cukup signifikan. Dan pada Perkembangan pangsa pasar syariah ini cukup menggembirakan namun belum diikuti dengan penerapan prinsip etika bisnis islam yang maksimal. Namun pada bank syariah telah menerapkan prinsip etika bisnis islam dalam kegiatan operasionalnya dan juga memberikan sebuah panduan kepada para pihak pemangku kepentingan atau stakeholder, seperti: nasabah penabung, pemegang saham, investor, obligasi, bank responden, regulator, pegawai perseroan, pemasok, dan lingkungan masyarakat untuk mewujudkan akuntabilitas publik dalam melakukan upaya keputusan ekonomi.
\end{abstract}

Kata Kunci: Etika bisnis, hukum syariah, Islam, stakeholder, investor 


\section{Ad-Deenar}

\section{A. PENDAHULUAN}

Perkembangan bisnis syariah kini tengah banyak digunakan dan diminati oleh masyarakat, terlebih di Indonesia, hal ini disebabkan oleh adanya kesadaran masyarakat Indonesia yang mayoritas muslim untuk senantiasa menggunakan produk yang hal dan juga tayyib. Maka dengan ini, tentu juga menimbulkan setiap perusahaan mulai beroperasi, memproduksi sesuai dengan prinsip syariah. (Huda, 2016)

Beriringan dengan hal tersebut, menyebabkan timbulnya berbagai macam produk syariah yang digunakan oleh berbagai prusahaan. Dimana ini menimbulkan kekhawatiran kesesuaian perusahaan dengan hukum syar'i dalam menerapkan produk ataupun praktek bisnis syariah, karna dalam penerapannya tidaklah cukup hanya berganti nama saja. (Huda, 2016)

Dengan adanya kekhawatiran tersebut, maka penting bagi setiap pelaku bisnis untuk menjalankan prkatek bisnis syariah yang sesuai dengan etika islam yang sesuai dengan al-qur'an dan as-sunnah. (Antoni, 2018, p. 2) terdapat beberapa etika bisnis islam yang perlu diperhatikan, diantaranya kejujuran, memberi manfaat pada orang lain, dilarang menipu, dilarang menjatuhkan bisnis orang lain, dilarang iktikar, dilakukan atas dasar suka sama suka, dilarang monopoli, objek bisnis harus halal, serta memberikan upah tepat waktu atau sebelum kering keringatnya, dan tidak mengandung unsur riba. (Mardoni)

\section{B. PEMBAHASAN}

\section{Pengertian Etika Bisnis}

Etika sangatlah penting dalam kehidupan bermasyarakat, baik dalam bersosialisasi maupun berbisnis. Etika merupakan ilmu filsafat yang mencari kebenaran atas nilai-nilai baik dan buruk yang berkaitan dengan perilaku sesorang (Baidowi, 2011) (Aziz, 2013). Etika juga diartikan sebagai suatu penjelasan mengapa hal yang seseorang lakukan itu buruk atau salah. Sedangka Bisnis adalah perorangan atau sebuah organisasi yang menjual suatu barang atau jasa kepada para konsumen atau para pebisnis lainnya untuk memperoleh suatu keuntungan atau laba.

\section{(Aziz, 2013)}

Etika Bisnis merupakan cara untuk melakukan suatu kegiatan bisnis yang mengaitkan aspek yang berkaitan dengan personal, perusahaan, obyek bisnis,dan masyarakat. Mencakup bagaimana pebisnis menjalankan bisnis secara adil, dan sesuai hukum berlaku. (Baidowi, 2011) Dan juga merupakan ilmu standart dalam dunia bisnis yang bagaimana standar tersebut diterapkan dalam lingkungan bisnis, organisasi, industry dan perusahaan yang baik dan menjaga nama baiknya. 
Etika Bisnis Islam adalah suatu proses untuk mengetahui sesuatu hal yang benar dan salah yang akan dikaitkan dengan suatu produk, pelayanan perusahaan dan perilaku atau pelayanan individu dalam bisnis yang dijalankan sesuai pada nilai-nilai syariah islam yang telah ditentukan. (Aziz, 2013)

\section{Prinsip-Prinsip Etika Bisnis Islam}

Bisnis menjadi bagian tak terpisahkan dari kegiatan ekonomi. Hampir seluruh aspek perekonomian menjalankan bisnis untuk memutar roda perekonomian. Dalam era sekarang praktik bisnis menjadi semakin terbuka dan marak digunakan, baik melakukan bisnis secara online maupun secara offline. Untuk zaman yang milenial sekarang, banyak dari kalangan muda yang merintis bisnis secara online, banyaknya praktik bisnis membuat banyak persaingan ketat untuk menarik konsumen, setiap pebisnis memiliki strategi tersendiri dalam menjalankan usahanya.

Aktifitas bisnis bagi umat muslim bukanlah menjadi aktifitas yang baru. Dalam Al-Qur'an telah dijelaskan mengenai bisnis, dalam Al-Qur'an bisnis secara bahasa disebut sebagai "al-tijarah" yang berarti niaga atau dagang.

Bank syariah juga melakukan transaksi tijarah ini, bisnis bukan lagi hanya tentang jual dan beli namun juga terdapat beberapa akad bisnis yang diterapkan diantaranya adalah akad kerjasama, seperti mudharabah, musyarakah, muzara'ah dan sebagainya.

Dalam menjalankan sebuah bisnis, terdapat beberapa prinsip yang diterapkan, terlebih apabila menerapkan prinsip islam, harus berdasarkan prinsip Al- Qur'an dan Hadist, dijelaskan dalam (Aziz, 2013) beberapa dasar etika bisnis islam beradsarkan Al-Qur'an:

a. Barometer Kataqwaan Seseorang. Allah SWT berfirman (QS. AlBaqarah, 2: 188)

b. Mendatangkan Keberkahan. Allah SWT berfirman (QS. Al-A'raf, 7: 96)

c. Mendapatkan Derajat Seperti Para Nabi, Shiddiqin \& Syuhada Rasulullah SAW bersabda:

$$
\begin{aligned}
& \text { عن أبي سعيد عن البي صلى الله عليه } \\
& \text { و سلم قال التاجر الصدوق الا مين مع } \\
& \text { المبين و الصديقين و الشهداء }
\end{aligned}
$$

"Dari Abu Sa'id Al-Khudri ra beliau berkata bahwa Rasul Allah SAW.bersabda,"Pebisnis yang jujur lagi dipercaya (amanah) akan bersama para nabi, shiddiqin dan syuhada". (HR. At-Turmudzi)

Dalam hadist tersebut dijelaskan bahwa, dalam berbisnis hendaklah berbisnis dengan jujur, sebagaiamana berniaga dengan ajaran Rasulullah.

d. Berbisnis Merupakan Sarana Ibadah Kepada Allah SWT. Banyak ayat yang menggambarkan bahwa aktivitas bisnis merupakan sarana 


\section{Ad-Deenar}

\section{Jurnal Ekonomi dan Bisnis Islam}

ibadah, bahkan perintah dari Allah

SWT. Diantaranya adalah (QS.

AtTaubah, 9: 105)

Dari beberapa yang sudah disebutkan diatas, telah dengan jelas bahwa dasar dari etika bisnis islam sesuai dengan Al-Qur'an dan Hadist, oleh karenanya apabila kita melkaukan sebuah usaha, perlu memgang ajaran dasar dari Al-Qur'an dan Hadist tentang Bisnis.

Dalam dunia perbankan syariah, juga perlu menerapkan etika bisnis islam, sesuai dari Al-Qur'an dan Hadist , bank syariah sendiri dalam operasional nya juga perlu menggunakan prinsip dari etika bisnis islam. Penerapan prinsip etika bisnis Islam dalam praktik perbankan syariah merupakan persyaratan mutlak yang harus dipenuhi menurut tuntunan syariat agama Islam dan sebagai identitas pembeda antara bank syariah dengan bank konvensional (Putritama, 2018)

Menurut (Alfaqiih, 2017), Praktik bisnis mesti mengacu prinsip-prinsip dasar yang mencerminkan nilai-nilai luhur yang universal. adapun beberapa prinsip etika bisnis islam yang perlu diterapkan dalam bisnis kita :

a. Prinsip tauhid, prinsip ini menegaskan bahwa Allah adalah pemilik sejati seluruh yang ada di alam semesta ini. Oleh karena itu, dalam melaksakan sebuah bisnis, segala barang yang diperjualbelikan hanyalah milik Allah SWT.

b. Prisnip Keadilan, Prinsip ini mengajarkan manusia agar dapat berlaku adil dalam segala hal, terutama dalam kontek bisnis. Sebagai pelaku bisnis, perlu kita melakukan sikap adil kepada konsumen, tidak membedakan konsumen satu dan lainnya, serta berdagang dengan cara yang baik.

c. Prinsip Nubuwah (kenabian), Prinsip ini menegaskan bahwa Nabi

Muhammad merupakan model yang ideal dalam segala perilaku, diantaranya perilaku yang diteladani adalah jujur dan amanah.

d. Prinsip Khilafah, Fungsi utamanya adalah untuk menjaga keteraturan interaksi (mu'amalah) antar pelaku bisnis, agar dapat meminimalisir kekacauan, persengketaan, dan keributan dalam aktivitas mereka.

e. Prinsip Hasil, prinsip yang dimaksudkan adalah apabila kita menjalankan muamalah sesuai dengan prinsip islam, maka hasil yang didapat tidak hanya hasil yang diperoleh pada saat di dunia, namun juga mendaptkan pahala di akhirat kelak. 


\section{Konsep Etika Dalam Al-Qur'an}

Al-qur'an biasa disebut sebagai pedoman dalam suatu etika pada kehidupan, salah satunya sebagai tuntunan manusia dalam melakukan perdagangan. Sebab didalam Al-qur'an sebagai karunia yang diberikan oleh Allah SWT sebagai petunjuk bagi manusia dan sebagai pengetahuan antara kebenaran dan kebathilan.

Dalam surah Al-Baqarah ayat 185 dijelaskan : “(Beberapa hari yang ditentukan itu ialah) bulan Ramadhan, bulan yang di dalamnya diturunkan (permulaan) Al Quran sebagai petunjuk bagi manusia dan penjelasan-penjelasan mengenai petunjuk itu dan pembeda (antara yang hak dan yang bathil). Karena itu, barangsiapa di antara kamu hadir (di negeri tempat tinggalnya) di bulan itu, maka hendaklah ia berpuasa pada bulan itu, dan barangsiapa sakit atau dalam perjalanan (lalu ia berbuka), maka (wajiblah baginya berpuasa), sebanyak hari yang ditinggalkannya itu, pada harihari yang lain. Allah menghendaki kemudahan bagimu, dan tidak menghendaki kesukaran bagimu. Dan hendaklah kamu mencukupkan bilangannya dan hendaklah kamu mengagungkan Allah atas petunjuk-Nya yang diberikan kepadamu, supaya kamu bersyukur."

Al-Qur'an tidak hanya sebagai petunjuk bagi manusia tetapi juga sebagai pembenar dan penguji kitab suci agama lain. Allah SWT bersabda dalam surah AlMaidah ayat 48:

Dan Kami telah turunkan kepadamu Al Quran dengan membawa kebenaran, membenarkan apa yang sebelumnya, yaitu kitab-kitab (yang diturunkan sebelumnya) dan batu ujian terhadap kitabkitab yang lain itu. Maka putuskanlah perkara mereka menurut apa yang Allah turunkan dan janganlah kamu mengikuti hawa nafsu mereka dengan meninggalkan kebenaran yang telah datang kepadamu. Untuk tiaptiap umat diantara kamu, Kami berikan aturan dan jalan yang terang. Sekiranya Allah menghendaki, niscaya kamu dijadikan-Nya satu umat (saja), tetapi Allah hendak menguji kamu terhadap pemberianNya kepadamu. Maka berlomba-lombalah berbuat kebajikan. Hanya kepada Allah-lah kembali kamu semuanya, lalu diberitahukan-Nya kepadamu apa yang telah kamu perselisihkan itu.

Al-Quran sudah memuat banyak konsep-konsep pada etika yang bertujuan untuk memberikan sikap-sikap yang benar bagi tindakan yang dilakukan oleh manusia., baik dalam tindakan politik, sosial ekonomi terutama dalam perdagangan. (Hendar Riyadi 2007)

Secara garis besar bahwa Al-Qur'an sebagai ajaran etika beserta seruan-seruan 
moral bukan hanya sebagai dokumen hukum.

Suatu konsep etika bisnis islam dibutuhkan suatu penanganan yang khusus untuk merumuskan secara sistematis yang berfungsi sebagai panutan dalam suatu kehidupan, terutama dalam hubungan perdagangan. Etika ini sanagat diperlukan supaya tiap insan dapat melakukan kehidupan secara kerjasama dalam melindungi kepentingan bersama yang berkeadilan didalam lingkungannya. (George F. Hourani)

Dalam dasar etika bisnis islami merupakan suatu ketauhidan, ada beberapa konsep etika bisnis dalam Al-Quran diantaranya:

a. Tauhid atau Dasar Moralitas Qur'ani bagi kaum Beriman.

Dalam etika fundamental Al-Quran lah yang menjadi salah satu dasar teologi islam beserta pengajaran dalam wawasan keagamaan dan dalam hubungan sosial umat insan dalam berbagai aspek yaitu tauhid. Tauhid merupakan suatu pijakan etika islam yang dilihat dari nilai islam. Rasulullah diutus oleh Allah SWT untuk memperbaiki etika masyarakatnya. Maka dari itu perlunya

(Peniruan Etika Tuhan" sebagai salah satu jalan untuk memperbaiki moral insan.
Ada lima etika ketuhanan sebagai suatu landasan untuk pembentukan moral insan diantaranya:

1) Insan yaitu pengasih.

2) Barr yaitu pemulia.

3) Ghafur yaitu pemaaf.

4) Rahim yaitu penyayang dan.

5) Insan yaitu berbuat baik atau professional.

Salah satu dosa terbesar yang tidak bisa diampuni oleh Allah SWT yaitu menjadikan Tuhan selain Allah atau syirik, jika dilihat secara teologis tidak akan diterima sebagai salah satu akidah yang benar, malainkan mengakibatkan suatu perendahan terhadap harkat dan martabat insan yang dimuliakan Allah SWT.

Sejak awal tauhid sudah digambarkan sebagai suatu dasar fundamental dalam mencipakan suatu tata sosial yang berlandasan moral, kejujuran dan keadilan, permainan kotor dalam suatu perdagangan, tanpa adanya tanggung jawab sosial dan eksploitasi kaum miskin.

Dalam Al-Qur'an surah AlAn'an ayat 151-152 menejelaskan semangat profetik dari sebuah ide tauhid:

Katakanlah: "Marilah kubacakan apa yang diharamkan atas kamu oleh Tuhanmu, yaitu: janganlah kamu 
mempersekutukan sesuatu dengan

Dia, berbuat baiklah terhadap kedua orang ibu bapa, dan janganlah kamu membunuh anak-anak kamu karena takut kemiskinan. Kami akan memberi rezeki kepadamu dan kepada mereka; dan janganlah kamu mendekati perbuatan-perbuatan yang keji, baik yang nampak di antaranya maupun yang tersembunyi, dan janganlah kamu membunuh jiwa yang diharamkan Allah (mem- bunuhnya) melainkan dengan sesuatu (sebab) yang benar". Demikian itu yang diperintahkan oleh Tuhanmu kepadamu supaya kamu memahami (nya). Dan janganlah kamu dekati harta anak yatim, kecuali dengan cara yang lebih bermanfaat, hingga sampai ia dewasa. Dan sempurnakan lah takaran dan timbangan dengan adil. Kami tidak memikulkan beban kepada seseorang melainkan sekedar kesanggupannya. Dan apabila kamu berkata, maka hendaklah kamu berlaku adil kendati pun dia adalah kerabat (mu), dan penuhilah janji Allah. Yang demikian itu diperintahkan Allah kepadamu agar kamu ingat,",

Dalam dua ayat tersebut menjelaskan menempatkan tauhid pada urutan yang pertama selanjutnya disusul dengan berbagai suatu ketentuan pada kehidupan moral lainnya. Dalam hal ini menegaskan bahwa tauhid dalam visi al-Qur'an adalah sebuah dasar fundamental bagi seluruh kesalahan, religuitas terutama bagi kebaikan moral, misalnya birul walidain terhadap kedua orang tua dan menjaga generasi.

Dengan penjelasan tersebut menjelaskan bahwa konssep tauhid tidah hanya sekedar paradigma metafisik melainkan sebagai suatu dasar etika sosi ekonomi. (Komarudin Hidayat)

Pada skematis diatas menjelaskan bahwa Tuhan yang Berada diatas manusia artinya bahwa manusia adalah makhluk Allah yang harus tunduk dan patuh pada tuhanNya baik secara lahir maupun batin da memasrahkan diri kepada Tauhid supaya menjadi pusat segalanya (Allah as-Shamad), sementara gambar pada sebelah kiri posisi Tuhan yang sejajar dengan manusia sehingga dapat menyebabkan perbuatan syirik, kenapa? Karena sama halnya mempersekutukan Allah. Perbuatan ini adalah suatu kekufuran dan 


\section{Ad-Deenar}

kedzaliman yang tidak akan diampuni oleh Tuhan.

b. Iman, Islam, Ihsan

Dari empat konsep tetralogy etika religious dalam Al-Quran yang salah satunya mengandung suatu gagasan pokok yang sangat pentning dalam suatu moralitas kemanusiaan, terkhusunya pada suatu masalah antara hubungan sosial diantara umat islam salah satunya yaitu iman, islam dan ihsan. Salah satu puncak tertiggi adalah ketaqwaan dari tiga kata tersebut, tidak hanya milik islam saja tetapi juga sebagai dasar risalah asasiyah. (Hendar Riyadi 2007)

a) Iman

Iman yang memiliki arti percaya, berasal dari sebuah kata a-m-n yang memiliki arti dalam keadaan damai dengan diri sendiri . Allah berfirman dalam Surat al-Quraisy ayat 4 yang berbunyi : "yang telah memberi makanan kepada mereka untuk menghilangkan lapar dan mengamankan mereka dari ketakutan".

Dalam ayat diatas menjelaskan bahwa iman yang terbaca amana adalah suatu wujud dari rasa aman dari suatu ketakutan. Maksutnya orang-orang yang beriman akan terhindar dari ketakutan. Dan sangat peduli terhadap sesame, tanggung jawab ini muncul dari sebuah kesadaran imannya.
Sedangkan yang mengandung penderita yaitu dengan huruf tambahan baa tau lam. Allah berfirman dalam surat al-Baqarah ayat 136 :

Katakanlah (hai orang-orang mukmin): "Kami beriman kepada Allah dan apa yang diturunkan kepada kami, dan apa yang diturunkan kepada Ibrahim, Ismail, Ishak, Yakub dan anak cucunya, dan apa yang diberikan kepada Musa dan Isa serta apa yang diberikan kepada nabi-nabi dari Tuhannya. Kami tidak membeda-bedakan seorang pun di antara mereka dan kami hanya tunduk patuh kepada-Nya".

Kata iman yang berasal dari kata bahasa arab merupakan suatu kepercayaan maksutnya iman yaitu engkau percaya kepada Allah, MalaikatNya dan Kitab suciNya dan para utusanNya, hari kemudia dan engkau juga percaya adanya baik buruknya takdir yang ditentukan oleh Allah SWT. (Masjuk Zuhdi 1993)

b) Islam

Secara bahasa arab kata islam merupakan suatu ajaran yang bersifat penyerahan tunduk dan patuh terhadap apa yang sudah ditetapkan oleh Tuhan yang wajib dilakukan oleh manusia. Dalam al=Qur'an Surat al-Imra ayat 85 menjelaskan :

"Barang siapa mencari agama selain agama Islam, maka sekali-kali tidaklah akan diterima (agama itu) daripadanya, 
dan dia di akhirat termasuk orang-orang

yang rugi”.

c. Ihsan

Ihsan diartikan sebagai modal yang kini sudah menjadi sesuatu yang langkah. Hanya saja sedikit mereka yang berkomitmen dengan moralitas ini.

Berkenaan dengan adanya suatu perubahan tidak dikhusukan hanya keada kaum umat islam saja tetapi juga pada seluruh penduduk yang ada di bumi.

Pada suatu perubahan yang tidak dikhusukan hanya kepada umat islam tetapi juga kepada seluruh penduduk yang ada di muka bumi ini. Allah mengatakan dalam Q.S Al-Ra'ad ayat 13: "Sesungguhnya Allah tidak akan mengubah keadaan suatu kaum, sehingga mereka mengubah keadaan yang ada pada diri mereka sendiri”. (Amru Khalid 2005)

Jadi islam menggambarkan bahwa Allah SWT memperkenalkan diri melalui wahyuNya yang pada saat itu diemban oleh Nabi Muhammad SAW dengan membawa ajaran yang Allah peritahkan kepada beliau yang menyangkut tiga ajaran diantaranya Iman, Islam dan ihsan tanpa ada yang mendahului dan tanpa ada yang mengakhiri.

Intinya dalam tiga ajaran ini wajib dipraktekkan secara baik tanpa ada perpisahan dalam dalam tiga ajaran.

\section{Konsep Bisnis Dalam Hadist}

Hadist merupakan salah satu sumber pokok dalam islam setalah Al-Qur'an. Didalam penjelasan Al-Qur'an bahwa manusia tahu cara bagaimana melaksanakan perintah yang ada didalam Al-Qur'an, karena hadist berasal dari Rasul yang merupakan sebagai panutan dalam melaksanakan ibadah kepada Allah. Hadist dijadikan panutan setelah Al-Qur'an untuk seluruh umat muslim termasuk dalam melakukan suatu bisnis. Yang dimana dalam melakukan pemahaman bisnis yang diukur dari aspek materi semata, dalam melakukan ukuran materi untuk semua aktivitas manusia dalam melakukan konteks bisnis dalam suatu cara untuk melakukan ibadah. Maka dalam berbisnis dalam bentuk berdagang maupun yang lainnya dengan adanya sebuah kejujuran dan keadilan, ini salah satu nilai ibadah dalam bisnis. Sebuah landasan berasal dari Al-Qur'an dan hadist Nabi SAW, ataupun dari Hasil ijtihad para ahli Islam dalam menerapkan sebuah prinsip Islam dengan secara utuh dan dalam kegiatan yang ada di ekonomi bisnis.

Dalam sebuah aspek ekonomi mempunyai sebuah peranan yang sangat penting dalam melakukan meningkatkan sebuah kesejahteraan hidup manusia. Dengan Seiringnya berjalannya perkembangan waktu dan pertumbuhan masyarakat serta kemajuan dalam bidang 


\section{Ad-Deenar}

ilmu pengetahuan dan teknologi, maka dalam hal itu terjadi sebuah perubahan terhadap pola kehidupan masyarakat dan tidak terkecuali dengan dalam bidang ekonomi yang termasuk tentang pada dalam bisnis. Dan didalam bisnis ini meningkatkan suatu kesejahteraan hidup dalam melakukan paradigma pengelolahan pertukaran barang dengan cara yang baik dengan sebuah paradigma bisnis. Seperti adanya sebuah monopoli yang ada didalam pasar hanya ada sebuah kemampuan yang melakukan bertindak dalam menentukan sebuah harga dengan cara sendiri dengan cara mengambil keuntungan yang diatas normal pada saat itu dengan cara menjual barang yang ingin didapatkan dengan harga yang tinggi, maka dalam satu kelompok atau kelompok yang lain untuk menguasai sebuah pemasaran barang dan produksi barang yang tertentu. Dalam monopoli yang ada dipasar dalam dunia pemasaran adanya sebuah satu penjual yang telah menguasai pasar.

Pada dalam pasar ekonomi mempunyai suatu tempat atau proses interaksi antara penjual dengan pembeli dari suatu barang atau jasa dan menetapkan suatu harga keseimbangan dan jumlah yang akan diperdagangkan, maka setiap proses akan mempertemukan antara penjual dengan pembeli untuk menentukan harga yang telah disepakati dalam melakukan jual beli. (SYARIFATUNNISA, 2014)

Ada beberapa hal yang harus dijadikan sebuah paradigma untuk mengelola suatu bisnis, yaitu:

a. Keimanan

Dalam konsep keimanan adalah keyakinan yang sempurna kepada Allah dan kepada hari kemudian. Didalam sebuah pasar banyak sebuah kekafiran, kefasikan dan kekejian. Maka seseorang akan melakukan aktivitas bisnis harus selalu mengingat allah dalam aktivitas mereka yang sedang sibuk dan harus memiliki sebuah kesadaran tinggi dan responsif dengan prioritas yang sudah ditentukan oleh Allah SWT.

b. Adil atau Keseimbangan

Untuk mewujudkan sebuah keadilan atau keseimbangan dalam kehidupan khususnya dalam melakukan dunia bisnis, maka Islam telah mengharamkan setiap hubungan bisnis yang mengandung kezaliman dan mewajibkan terpenuhinya keadilan yang teraplikasikan dalam setiap transaksi-transaksi bisnis yang dilakukan dalam melarang transaksi gharar. Sedangkan dalam mewujudkan keseimbangan juga 
adanya melarang sebuah transaksi tadlis yaitu transaksi berupa sebuah penipuan. Maka perbedaan dari kedua ini, ialah jika transaksi gharar penjual maupun pembeli tidak mengetahui kualifikasi barang yang akan ditransaksikan, sedangkan transaksi tadlis tidak ada yang mengetahui dakam satu pihak antara penjual dan pembeli.

Seorang manusia juga merupakan suatu mahluk sosial dan tidak bisa hidup tanpa adanya kerja sama, maka ada yang sebagian melayani dan ada yang sebagian yang lainnya, demikian dari sebagian untuk memberi atau menerima dari sebagian yang lain. Dan akan menggunakan konpensasi yang setimpal. Jika seorang tukang sepatu mengambil produk dari tukang jahit, dan tukang jahit memberi produk kepada tukang sepatu, maka diantara mereka terjadilah sebuah tukar menukar dan Saling tukar menukar ini adalah barter, jika misal nilai kedua produk itu sama. Maka tidak ada yang bisa mencegah nilai produk yang satu lebih tinggi dari produk lainnya. Maka dalam hal ini uanglah yang bisa menyamakan antara mereka. Oleh karena itu uang itu adil atau penengah diantara mereka. Cuma halnya uang itu bisu, sedangkan manusia bisa bicara. Manusia hanya bisa menggunakan uang, dan dengan uang manusia bisa mengatur segala yang terjadi dalam transaksi, sehingga transaksi dapat berjalan dengan benar, teratur dan adil. Oleh karena itu sangat dibutuhkan seseorang yang dapat menegakkan keadilan, karena ternyata uang hanyalah merupakan penegak keadilan yang bisu.

c. Kehendak Bebas (Free Will).

Dalam kehendak bebas ini memiliki sebuah Konsep yang kemudian menentukan sebuah pasar islami bisa menjamin adanya sebuah kebebasan terhadap masuk keluarnya barang atau sebuah komoditas di pasar. Maka hal ini yang dimaksud untuk menjamin adanya pendistribusian kekuatan ekonomi islam dalam sebuah mekanisme yang proporsional. Bahwa didalam otoritas pasar tidak boleh membatasi elemen pasar pada peran industri tertentu, karena hal ini dapat membawa adanya perilaku monopolistik, dimana produktivitas sebuah industri dapat dibatasi untuk kepentingan kenaikan harga. Maka dalam sistem etika ekonomi islam yaitu adanya sebuah nilai moral dan 
spiritual yang melandasinya tanpa adanya filter moral, maka dalam kegiatan ekonomi akan rawan dengan munculnya sebuah praktik riba, monopoli, dan kecurangan akan membuat kerugian kepada masyarakat luas dan ini sudah menjadi tradisi.

d. Tanggung Jawab

Dalam konsep tanggung jawab ini memiliki sebuah hubungan dengan adanya konsep keimanan yang mana dalam segala aktivitas seseorang dalam kehidupan bisnis. Yang dimana jika seorang beriman tidak akan mungkin menaikan harga diatas harga yang normal, maka akan dimintai dengan pertanggung jawaban pada hari kemudian dan perbuatan itu akan dimurkai oleh Allah SWT, jika barang siapa yang akan mempermahalkan harga barang dagangan kepada orangorang muslim, maka allah akan menepatkan orang itu kedasar api neraka pada hari kiamat. Maka dalam pertanggung jawaban yang mendasar akan mengubah semua perhitungan ekonomi dan bisnis karena semua mangacu pada sebuah keadilan. e. Ihsan atau Kebajikan

Adanya sebuah ihsan dan kebajikan ini pada orang lain akan didefenisikan sebagai perbuatan baik dan memberikan manfaat kepada orang lain dan akan memberikan kemudahan dalam melakukan transaksi dengan menjual barang dengan harga yang wajar dan normal tidak menganiaya setiap saudara muslim dengan mangambil keuntungan yang sangat besar. (Darussalam, Paradigma Bisnis Islam Perspektif Hadis, 2015)

\section{Ciri dan bentuk monopoli pasar}

a. Monopoli terjadi karena adanya berbagai faktor, sehingga dapat penelian bentuk pasar pada suatu daerah yang mempengaruhi adanya terbentuknya monopoli.

b. Monopoli dapat terwujud adanya pemberian oleh Negara dengan menggunakan hak paten dengan monopoli yang akan terjadi karena adanya teknologi rahasia yang tidak bisa diikuti oleh produk lain. Maka tanpa harus mendapat pengakuan dari Negara teknologi sudah bisa melakukan monoopoli dengan sendirinya.

c. Adanya monopoli terjadi karena pemberian Negara. Di Indonesia 


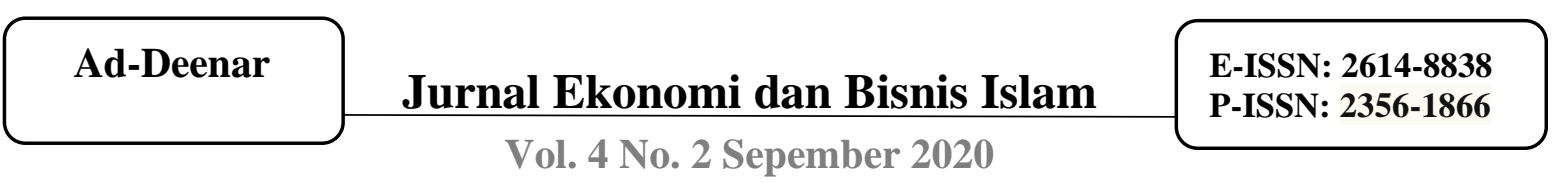

Vol. 4 No. 2 Sepember 2020

memiliki peraturan pelaksanaan UUD pasal 33 ayat 2 dan 3. Pada bunyi ayat 2 yaitu cabang produksi yang penting bagi Negara dan yang menguasai hajat hidup orang banyak yang dikuasai oleh Negara. Pada bunyi ayat 3 yaitu bumi, air dan kekayaan alam yang terkadang didalamnya dikuasai oleh Negara dan dipergunakan untuk sebesarbesarnya kemakmuran rakyat.

\section{KESIMPULAN}

Kegiatan Bisnis telah ada sejak dulu, umat muslim pun juga telah mempraktekkanya sejak dulu, memang kegiatan bisnis ini juga menjadi salah satu sumber ekonomi. Namu, ada beberepa etika yang perlu diterapkan dalam dunia bisnis. Terlebih apabila kita sebagai seorang muslim juga diharuskan menerapkan etika bisnis dengan prisnip islam, yang telah dijelaskan dalam Al-Qur'an dan Hadist.

Adapun beberapa prinsip yang perlu diterapkan dalam bisnis kita, diantaranya terdapat prinsip tauhid, keadilan, kejujuran, nubuwah, khilafah serta prinsip hasi; dimana dari kelima prinsip tersebut telah dipaparkan dalam jurnal ini.

Dalam Al-Quran sudah memuat banyak konsep-konsep pada etika yang bertujuan untuk memberikan sikap-sikap yang benar bagi tindakan yang dilakukan oleh manusia., baik dalam tindakan politik, sosial ekonomi terutama dalam perdagangan.

Di dunia bisnis pun terdapat sebuah paradigma untuk mengelola bisnis, yaitu keimanan, adil atau keseimbangan, kehendak bebas, tanggung jawab serta ihsan atau kebajikan.

Diharapkan pula, apabila kita melakukan sebuah bisnis dapat menerapkan prinsip-prinsip sesuai dengan Al-Qur'an dan Hadist, maka bisnis yang kita jalankan akan mengandung keberkahan, tidak hanya di dunia tetapi juga di akhirat.

\section{DAFTAR PUSTAKA}

Alfaqiih, A. (2017). Prinsip-prinsip Praktik Bisnis dalam islam bagi pelaku usaha muslim. Jurnal Hukum IUS QUIA IUSTUM .

Antoni. (2018). Etika Bisnis Perspektif Ekonomi Islam. Profit: Jurnal Kajian Ekonomi dan Perbankan, 2-3.

Aziz, A. (2013). ETIKA BISNIS PERSPEKTIF ISLAM Implementasi Etika Islami Untuk Dunia Usaha. Bandung: ALFABETA.

Baidowi, A. (2011). ETIKA BISNIS PERSPEKTIF ISLAM . Jurnal Hukum Islam .

Darussalam, A. (2015). Paradigma Bisnis Islam Perspektif Hadis. 24-40.

Huda, C. (2016). Model Pengelolaan Bisnis Syariah: Studi Kasus Lembaga Pengembangan Usaha Yayasan Badan Wakaf Sultan Agung Semarang. Walisongo: Jurnal Penelitian Sosial Agama, 166. 
Mardoni, Y. (n.d.). Etika Bisnis Perspektif Islam. Kewirausahaan dalam Multi Perspektif, 3437.
Putritama, A. (2018). Penerapan Etika Bisnis Islam dalam Industri Perbankan Syariah. Jurnal Nominal .

Syarifatunnisa. (2014). Etika Bisnis dalam Perspektif Hadis. 13-20. 